European journal of American studies

\title{
War and National Renewal: Civil Religion and Blood Sacrifice in American Culture
}

\section{Agnieszka Soltysik Monnet}

\section{(2) OpenEdition}

\section{Journals}

Electronic version

URL: https://journals.openedition.org/ejas/9672

DOI: 10.4000/ejas.9672

ISSN: 1991-9336

Publisher

European Association for American Studies

Electronic reference

Agnieszka Soltysik Monnet, "War and National Renewal: Civil Religion and Blood Sacrifice in American Culture", European journal of American studies [Online], 7-2 | 2012, document 6, Online since 04 April 2012, connection on 08 July 2021. URL: http://journals.openedition.org/ejas/9672 ; DOI: https:// doi.org/10.4000/ejas. 9672

This text was automatically generated on 8 July 2021.

Creative Commons License 


\title{
War and National Renewal: Civil Religion and Blood Sacrifice in American Culture
}

\author{
Agnieszka Soltysik Monnet
}

\begin{abstract}
1 Wars are often associated with a rhetoric of renewal or "new beginnings." Putting aside for a moment the possibility that this is only rhetoric, I would like to examine the conditions which allow war - sometimes - to function as an occasion for a new purchase on a shared sense of national identity and common purpose. One critical frame that brings such a proposition into focus is the sociology of religion and group identity founded by Emile Durkheim and developed in America since the 1960s in terms of the notion of civil religion. Specifically, I will consider a recent book which combines Durkheim's insights with Réné Girard's claims about the social function of ritualized sacrifice into a troubling argument about modern national cohesion as dependent on blood sacrifice. Even if many modern nation states define themselves as quintessentially secular and legal entities, inspiring healthy patriotism rather than overly emotional nationalism, they share with explicitly descent-based nationalisms a substratum of more "mystical" ideals and rituals. ${ }^{1}$ The most important, complex, and seemingly irrational of these is self-sacrifice for the common good or the group. This willingness, closely associated with military valor and patriotic heroism, is in fact essential to the cohesiveness and endurance of any group, argue Carolyn Marvin and David Ingle in their book, Blood Sacrifice and the Nation. Without it, a nation will not be able to defend itself and will not even want to. A nation that cannot inspire its members to lay down their life for it will inevitably fragment into clashing groups and lose its sovereignty.

2 Since the late eighteenth and early nineteenth centuries, the beginning of the age of the modern nation-state, patriotic sacrifice has been regarded as the noblest and most civilized gesture a man can perform for his country. Yet modern scholars of nationalism and national identity view self-sacrifice uneasily. While recognizing its central place in definitions of viable nations (those that produce a lasting sense of
\end{abstract}


coherence and continuity in their populations), historians and scholars of national identity are at pains to account for the intensity of attachment that would induce individuals to die for their nation. Moreover, the specter of Japanese suicide pilots and Islamic airplane hijackers, whose deaths may be understood as heroic sacrifices in their own cultural contexts but as terrorism in ours, complicates the work of distinguishing "appropriate" martyrdom from religious fanaticism. If, as Tom Nairn has suggested, the nation is "the modern Janus," no other aspect of national experience is more doublefaced than patriotic self-sacrifice. ${ }^{2}$ This essay will attempt to unpack some of the paradoxes raised by the notion of sacrifice in the context of US military history as well as the media treatment of the September 11 attacks, with a special focus on the sacred status of the flag and the ambivalent position of the soldier (and other uniformed servicemen such as police and firefighters). My final objective is to probe the theory of national renewal based on blood sacrifice advanced by Carolyn Marvin and David Ingle by testing its explanatory power for two images that have become iconic as representations of military service and sacrifice: Rosenthal's photo of the flag-planting at Iwo Jima and Thomas Franklin's photo of Ground Zero.

3 Any discussion of the relationship between war and national renewal should begin with the fact that most nations conceptualize and narrate their origins in terms of foundational wars. In France, this was the Revolution of 1789, in Germany, the conclusion of the Franco-Prussian War in 1871, and for many postcolonial nations, such as the United States, their war of independence. Many nations also structure their national histories around the subsequent wars that they waged with other nations or internally. These are the events that organize national history and they are sometimes (but far from always) associated with a regeneration of national cohesion and patriotic attachment. In the United States, the Civil War and the Second World War are widely regarded as the two most important military conflicts in terms of reorganizing national identity and renewing a sense of national purpose. World War I also had an important impact on the country, but its place in national memory is more controversial and complex due to the lack of clarity about its objectives in the minds of American citizens and soldiers alike. The many other wars conducted by the United States, e.g. the War of 1812, the Mexican-American War, the Indian Wars, the Spanish-American War, the Korean, Vietnam, and Persian Gulf Wars, may have generated brief moments of patriotic effervescence, gained territory and political and economic objectives, and produced important collective memories and rituals, but none of them can be said to have reset the clock of nation-time and boosted an enduring sense of national collective purpose in any way remotely like the Civil War and World War II. ${ }^{3}$

4 If America was "born" in the Revolutionary War, it is justifiable to say that it was "reborn" in the Civil War. Robert Penn Warren has claimed that the "The Civil War is, for the American imagination, the great single event of our history." "Before the Civil War, Warren contends, the United States "had no history in the deepest and most inward sense." John Neff has recently proposed that the Civil War produced two separate national ideologies which could each be called a civil religion: the Lost Cause of the South, and the "Cause Victorious" of the North. ${ }^{5}$ Yet, as most historians would agree, by the time the U.S. had entered into World War I, the Southern myth of its martyrdom had begun to converge with Northern narratives to produce a revisionist history that conceived of the Civil War as a shared experience of national suffering. This was the argument made by Woodrow Wilson's A History of the American People (1902) and was popularized by D.W. Griffith's film A Birth of a Nation (1914), which drew 
on Wilson's work for its historical claims. It was on this basis that Warren could claim that the Civil War gave the United States a history that it had not had before: as the foundation of a newly reconceived nation. Most historians would agree that American national self-understanding changed significantly during the Civil War. One concrete example of this transformation is the shift in usage from the plural to the singular in relation to the United States, as in "The United States is a republic" as opposed to "The United States are a republic." This shift is generally dated to around 1861, which is to say, the beginning of the Civil War, and helped American conceptualize the entity or cause they were fighting for (on the Union side, that is). ${ }^{6}$ Another example of how the Civil War helped create a sense of common national identity is the way in which it occasioned the founding of a national military cemetery system. Up until the Civil War, the bodies of slain American soldiers had not been retrieved systematically from battlefields nor been the objects of special reverence. It was in 1862 that, for the first time, the U.S. government decided to set aside, by Act of Congress, special cemeteries to bury the bodies of those who gave their lives in defense of the Republic, and an entire network of sacred national sites was thereby created. ${ }^{7}$

5 The single most famous formulation of the way in which war is linked to a discourse of national renewal is Abraham Lincoln's address at the dedication of one of the first of these national military cemeteries: the Soldier's National Cemetery at Gettysburg, Pennsylvania, in 1863, exactly midway through the Civil War. Lincoln's Gettysburg Address is a powerful mixture of political and religious rhetoric that should serve as a point of departure for any analysis of the notion of American civil religion. Although this concept no longer inspires the same intensity of debate as it did in the decade following Robert Bellah's influential essay on the subject in 1967, it remains a compelling framework through which to understand the emotional and quasi-mystical dimensions of American politics. ${ }^{8}$ Civil religion has been defined in a variety of ways, but I use it to refer to the way in which national institutions, rituals and ideologies function like a religion: dividing the world into sacred and profane spheres, providing constituents with a sense of supra-individual transcendence and collective continuity, and offering an emotionally satisfying frame for coping with death. If national civil religion resembles traditional religions in these three aspects, the modern nation has wrested from religion a fourth aspect that it now monopolizes completely: the power to kill non-members for the sake of its self-preservation and to ask members to die in its name. Currently, only the nation-state legitimately holds this right, which is why the nation can be said to have replaced religion in the social organization of death.

6 Lincoln's speech at Gettysburg offers a revealing blueprint of how religious notions structure American political ideology. The word "dedicated" is used seven times in this speech of 267 words. The first use is completely neutral, in the sense of "committed to" or "defined by": "Four score and seven years ago our fathers brought forth on this continent a new nation, conceived in liberty, and dedicated to the proposition that all men are created equal." However, in the next lines, Lincoln begins to rework the meaning of this word, pushing it steadily into a religious frame. For example, the third appearance of the term is synonymous to "consecrate" or set aside as sacred, without actually saying so explicitly: "We have come to dedicate a portion of that field, as a final resting place for those who here gave their lives that that nation might live."

7 To speak of "dedicating" a piece of land for burial purposes, while not in itself overtly religious, shifts the register of the term in a more religious direction by 
referring to an activity, that of burial, which had traditionally been a function performed by the church and not the state. Building upon this sense of the word, Lincoln repeats it once more in the next line, this time as an exact synonym of "consecrate," and reinforces this meaning by the even more explicitly religious verb "to hallow."

8 In other words, "dedication" has at least two different meanings in the Gettysburg Address: that of committing one's self to a course of action or program, and a setting aside for religious or special purposes. When Lincoln says in the third paragraph that "we can not dedicate" this ground, he performs a subtle but significant confusion between the two senses. By arguing that the battle itself has "consecrated" the land, Lincoln shifts from the neutral to the religious sense of the word and moreover implies that the battle itself is somehow sacred. Sociologically, in the light of Durkheim's theory, which locates the sacred in the experience of the collective, this makes sense, i.e. the battle is sacred because it is about the fate of the nation.

9 The concepts invoked here, i.e. dedication, consecration, and devotion, are used in ways that need to be understood not only for their rhetorical value but for their ritual and performative function in the context of the official event at which they are uttered: the dedication of one of the very first war cemeteries. Lincoln was not only dedicating this one cemetery, he was defining the meaning and purpose of the war cemetery as a national institution. In doing so, he articulated one of the most enigmatic paradoxes of national identity: namely, that it is strengthened by the lives that are lost in its name. The "devotion" inspired in the survivors by the sacrifice of the dead produces a "new birth of freedom," a phrase that refigures the deaths of the soldiers into an image of birth linked to national identity through the word "freedom" (a term which vaguely but unmistakably signifies "America"). In other words, death, figured and understood as willing sacrifice, invests the nation with a sense of purpose, collective feeling, and renewed unity. Although Lincoln's speech invokes this transformative magic by which death becomes a "new birth," it does not explain how it works. ${ }^{9}$ After all, the many deaths at Gettysburg could seem to dilute the cohesion of the Union and be figured as a tragedy to be regretted rather than an occasion for regeneration. The logic by which death re-energizes national solidarity and cohesion can best be understood through the disciplines of sociology and anthropology and will be examined in a moment.

10 Since the Civil War, only World War II has come close to playing a comparable role of renewing a sense of sacred feeling and common purpose. ${ }^{10}$ In both cases, I am referring to a sense of collective unity that is articulated most clearly after the fact, in the national narrative and memory that finally takes stock of the event, and do not wish to eclipse the complexity of cultural forces that were in play during the actual events. During the Civil War, there were riots by draft resisters, and many Americans on both sides of the conflict felt that the price to pay for Union and Emancipation was far too high. American participation in the Second World War also had its opponents and critics, even after the attack on Pearl Harbor. Nevertheless, World War II has been dubbed "The Good War" in common parlance because of its seeming moral clarity. The dropping of the atomic bomb and the firebombing of German cities may have tainted the moral high-ground claimed by the Allies for some observers, but the Second World War has nevertheless entered American national memory as the most important episode of collective effort and public solidarity in the twentieth century. Former New 
York Governor Mario Cuomo recalls the Second World War as the "last time that this country believed anything profoundly, any great single cause":

We are good, they are bad. Let's all get together we said, and we creamed them. We started from way behind. We found strength in this common commitment, this commonality, community, family. The idea of coming together was best served in my lifetime in the Second World War. ${ }^{11}$

11 Besides evoking a Manichean moral simplicity commonly associated with WWII, Cuomo's description of the war is most revealing in its curious last phrase: the idea of coming together being "best served" by the Second World War. "Coming together" is necessary for any group that wants to endure, and Cuomo's slightly awkward phrasing inadvertently suggests that war is a means of fulfilling this need. The currently recognized effectiveness of the Second World War in performing this function is clear from Cuomo's emphatically redundant description of the unparalleled solidarity it created: "this common commitment, this commonality, community, family." As if this series of cognates of "common" were not enough, Cuomo follows up with the phrase "coming together," emphasizing that the unity he describes does did not emerge automatically from a natural solidarity but is more accurately described as a defensive reaction to an outside threat, so therefore necessarily ephemeral. Rapturous accounts of World War II unity are inevitably either eulogies or jeremiads, but their shared trait is a regret that the sense of cohesion did not last longer.

12 Nonetheless, even if the glow of World War II as a collective experience faded in the decades that followed, and was overshadowed by the divisive war in Vietnam and other crises of political authority, it can be said that World War II still remains for the time being the most effective functional paradigm for interpreting large-scale death in a national narrative. This became especially clear during the Sept. 11 attacks in New York. Although the initial comparison that many commentators made was with Pearl Harbor, the image that dominated the media in the weeks after the attacks (and which has since been immortalized as a postage stamp), Thomas Franklin's photo of firefighters raising a flag, drew comparisons with a very different World War II event: the planting of the flag on Iwo Jima. If the comparison with Pearl Harbor needs no explanation (though it certainly requires qualification), the logic of mapping Joseph Rosenthal's famous photograph onto the rubble of the Twin Towers deserves careful unpacking. Why should that image of territory-marking in the Pacific be a framework for mediating and understanding the attack on New York? What exactly is the connection, besides the compositional similarity of the photos? One obvious answer is the "rising from the rubble" metaphor suggested by the devastated landscape of both images. Yet this answer is not entirely satisfying since the devastated landscape on Iwo Jima is foreign land and the flag-raisers are the authors rather than victims of an attack. In other words, the rubble is not theirs to rise from.

13 I would suggest that Iwo Jima was invoked in the wake of 9/11 for another reason: its depiction of American sacrifice as a ritual of national regeneration. Although the photo is generally understood to signify victory, it is also understood to evoke the high cost of that victory. The fact that Iwo Jima was one of the bloodiest landings of the Pacific campaign is indissociably linked to the cultural status of the photo. Among the various meanings attributable to the Rosenthal photo, then, mass death is one. In fact, as Clint Eastwood's 2006 film, Flags of Our Fathers, reminded us, three of the six soldiers in the Rosenthal photo died in the days following the picture-taking (the photo was 
taken on the third day of a month-long battle). However, instead of depicting corpses or wounded men, as many war photos do, the photo depicts in the most vivid possible terms the loyalty of American troops to the American flag and therefore to America (the photo depicts this regardless of the question of whether the soldiers actually felt such patriotism or had simply been ordered to raise the flag). The tacit message behind this deliberately choreographed show of patriotism is that these young men are willingly fighting and dying for America. ${ }^{12}$ In Blood Sacrifice and the Nation, Marvin and Ingle argue that only willing self-sacrifice can function successfully to create a sense of national renewal. Soldiers and other uniformed servicemen, by definition, are understood to be willing to lay down their lives for the nation or for others. In other words, the photo of the flag-raising on Iwo Jima became such a powerful and popular icon of military service because it shows soldiers demonstrating their loyalty to the flag, and thereby to the nation it represents, in a clear and unambiguous tableau, against an invisible backdrop of massive fatality. The fact that the deaths at Iwo Jima can therefore be considered willing sacrifices gives them great ritual power in terms of generating the "heightened devotion" invoked by Lincoln at Gettysburg.

14 Accordingly, it could be argued that the American media invoked Iwo Jima as an interpretive schema to make sense of the Sept. 11 attacks in order to frame them in the regenerative terms of national sacrifice. Yet, since most of the 2976 people who died in those two buildings were not willing sacrifices, unlike soldiers in battle, they did not fit well in this narrative. Marvin and Ingle's insistence that group members must seem willing to die for the group in order for their deaths to successfully generate group cohesion can help explain the way firefighters and other uniformed public servants became the almost obsessive focus of the national media in the weeks following the attacks. It is particularly striking how much emphasis was placed on the volunteer aspect of their commitment to their work. The thirst for narratives of self-sacrifice was so strong that one woman, Tania Head, became nationally famous for her fraudulent account of being saved by a man who then went back into one of the towers and died. The revealing thing about this hoax is that the perpetrator did not invent a story of her own miraculous escape or heroism but a story of someone else's heroic death. ${ }^{13}$ She intuitively sensed that self-sacrifice generates far more emotional and symbolic currency than survival, no matter how lucky.

15 If the immediate reaction of the media was to read the Sept. 11 attacks in terms of World War II frames of reference, President Barack Obama gestured rhetorically back to Gettysburg in his speech commemorating the attacks in 2009. Calling on the American public to make Sept. 11 serve as an occasion for national renewal, Obama said: "On a day when others sought to sap our confidence, let us renew our common purpose, let us remember how we came together as one nation, as one people, as Americans united." Echoing Cuomo's description of World War II, Obama invokes the ideals of "coming together," a "common purpose," "one nation" and "one people." Speaking of the death of nearly 3000 Americans as an occasion for unity, Obama invokes the familiar rhetoric of national renewal based on mass death.

16 In order better to understand how a compelling sense of national unity and renewal can be generated by a massacre like the Sept. 11 attacks, we need to look into sociology and specifically the concept of civil religion, which is concerned with the religious or emotional aspects of nationalism. This is a field that historians shy away from because it does not lend itself to the same kind of empirical analysis as political speeches and 
historical events - yet it exerts a fascination because it represents the unexamined core of patriotism as attachment or strong feeling that is defined precisely by a willingness to die for one's country. Benedict Anderson's Imagined Communities (1983), one of the most influential recent works on national identity, begins and ends with attempts to reflect on this question and yet consistently shies away from engaging with it head on.

In the preceding chapters I have tried to delineate the processes by which the nation came to be imagined... But it is doubtful whether either social change or transformed consciousness, in themselves, do much to explain the attachment that people feel for the inventions of their imaginations--or, to return to a question raised at the beginning of this text-- why people are ready to die for these inventions. ${ }^{14}$

17 As Anderson reminds his readers in this passage, the processes of national identity formation through media and shared texts do not fully account for the power of these attachments. Anderson can only express puzzlement at the force of these feelings, which he consistently equates with and defines by the willingness to sacrifice one's life for the idea of the nation. It is this willingness that motivates yet eludes his efforts at analysis, as they focus on tangible institutions such as museums, newspapers, the census, and other inventions of written culture. However, the willingness to die for one's group is not an invention of the nation state. It has a far longer pedigree and can attach itself to groups of any size. Nevertheless, the nation-state is currently the only group that can legally demand its members to sacrifice themselves for its sake. ${ }^{15}$

18 The social theorist whose work has been the most pertinent to this issue is Emile Durkheim, especially in his late work Elementary Forms of Religious Life (1915). Durkheim's most influential idea in this study is that social belonging is essentially the root of religion, since religious feelings (i.e. awe, submission to a greater power, and a sense of the sacred and profane) originate in the admiration and fear that the individual feels before the power of the collectivity. The collectivity has the power to protect or to harm the individual, and so the individual's basic attitude towards the group is necessarily an ambivalent one of attraction/attachment and awe/terror. Durkheim argues that every human society makes a distinction between the sacred and profane and that this too is rooted in collective experience. That which is set aside as "sacred" is invested with the meaning and the power which is basically that of the group, i.e. it is a sign for the collectivity. In the aboriginal tribes that Durkheim used as the basis of his theory, the sacred takes the form of a totem. Durkheim further argues that the religious practices of aboriginal tribes are able to reveal the universal traits of all religions and all societies. Their "primitivism" does not make them qualitatively different from the monotheism of more" advanced" societies, but gives them rather the status of basic common denominator or structural skeleton of all religions. Interestingly, when Durkheim casts about for a modern equivalent to the totem, he does not cite the Christian cross but the national flag. ${ }^{16}$ Flags are our modern totems insofar as they are the emblems that represent the most widely respected collective units, not tribes in our case but nation-states. In Durkheimian sociology, then, the modern equivalents of totem and tribe are flag and country.

19 This insight intersects with some of the work done in the field of civil religion. However, much of the work on American civil religion in the 1970s that followed Robert Bellah's attempt to apply Durkheimian notions to American culture may have misconceived the location of the sacred in American society. While scholars debated 
the interpenetration of religion and politics in Presidents' speeches and the supposed sanctity of the Constitution in American politics, the totemic status of the flag as an embodied symbol of American sovereignty was largely overlooked. In other words, historians focused on texts, myths and rhetoric, but ignored the quasi-religious rites and sacred objects that could define American civil religion. Yet, when we think of the omnipresence of the American flag at official ceremonies, government offices, public buildings, schools and sports events, as well as the elaborate rules that govern its fabrication, handling and disposal, it is impossible to deny that there is an element of the sacred attached to this object. ${ }^{17}$ More striking still is the way in which the bodies of dead soldiers are ritualistically covered by flags, and how flags are given to families in lieu of the body of the slain soldier. There is a physical continuity between the flagbody and the soldier-body that Durkheim's theory of the religious basis of society goes further towards explaining than any official account of why flags are given to soldiers' families. Finally, not only the intense emotions around flag-burning and flag desecration, but the various Supreme Court decisions concerning the treatment of the flag suggest that it is not explicitly treated as a religious object only because its status is regarded tacitly as higher than any other religious symbol. ${ }^{18}$ This is the point missed by Robert Bellah and other scholars: civil religion does not function like other existing religions because it transcends them in relation to the collectivity as a whole. While many people have abandoned religious beliefs and practice, it is almost impossible to have no nationality. Even people who have lost their citizenship one way or another usually consider themselves as "belonging" to some nation in at least a spiritual and cultural sense. The main point here is that nationality is generally the first and most important way that social life on this planet is organized. It commands the most primary emotions and its leaders, representatives, institutions, and flags require the highest degree of respect. ${ }^{19}$

20 While the claim that the American flag is a kind of totem may still be accepted by most historians, Marvin and Ingle's argument that the nation is regenerated most effectively by blood sacrifice is more problematic. This is where Réné Girard's work on the sacrifice comes in. In Violence and the Sacred (1972), Girard argued that societies are naturally rife with tensions and conflicts and that they can avoid internal violence only by directing this aggression towards a common object. This sacrificial scapegoat allows the group to maintain internal peace by being purged or destroyed. Similarly, Anthony Marx argues in a recent study of national origins that nation-states did not merely replace the Church, as is commonly accepted, but that they harnessed the exclusionary tactics and deep passions of religious identity into nationalist politics. ${ }^{20}$ Linking Christian martyrology to modern nation-formation,Marvin and Ingle argue that national cohesion is always constituted on the basis of a collective "victimage" or collective sacrifice. ${ }^{21}$ In other words, as nations tend to view their history in terms of foundational moments of collective sacrifice, such as wars of liberation or other moments of great loss of life, the intensity of their sense of national unity and loyalty is based on a sense of ongoing identification with these foundational sacrifices. Here we return to Abraham Lincoln's speech at Gettysburg and his hope that the casualties buried in that new war cemetery would inspire the living to "dedicate" themselves to the cause of American nationhood.

21 Although nationalistic rhetoric tends to rely heavily on the notion of sacrifice, and we are all familiar with such phrases in political speeches, the idea that nations might actually "need" members to be willing to die for them can appear prima facie as a 
revolting claim. For many modern subjects, the idea of the nation serves as a powerful ideal of community and social justice. Civic nationalism promises to transcend and reconcile ethnic, religious, and all other differences by congealing a disparate population into a kind of imagined family linked by citizenship and mutual solidarity, and it is in this utopian guise that the idea of the nation inspires powerful emotions in people across the political spectrum. Modern political theory defines the role of the nation-state primarily as one of protection: of nationals from non-nationals, and of citizens from each other. Therefore, nothing could seem more wrong (even "sacrilegious") than to propose that the nation might need members to die for it on a regular basis in order to sustain its sense of unity. Following Girard's contention that some rituals require participants to be unaware of their true meaning and function, Marvin and Ingle argue that the true nature of war as national sacrificial ritual is the object of a powerful taboo. Although willing sacrifices create powerful group feeling, and political speeches such as Lincoln's Gettysburg Address tacitly acknowledge this, the group or nation cannot know that it needs members to die or that it finds ways to send them to die. This fact cannot be explicitly articulated or understood or the ritual will not work.

22 The class of willing sacrifices that every viable nation possesses is its military, which is why soldiers are something like a priestly order: subject to strict selection, training, rules, and privileges. In the US, the mandatory Soldier's Oath binds the pledger to protect the Constitution and obey orders given by the President and his representatives: "I, _-_-_, do solemnly swear (or affirm) that I will support and defend the Constitution of the United States against all enemies, foreign and domestic; that I will bear true faith and allegiance to the same; and that I will obey the orders of the President of the United States and the orders of the officers appointed over me, according to regulations and the Uniform Code of Military Justice. So help me God." (Title 10, US Code; Act of 5 May 1960 replacing the wording first adopted in 1789, with amendment effective 5 October 1962). The mixture of national and religious rhetoric ("true faith", "So help me God," "appointed" officers) is striking for a nation which has made the separation of church and state a cornerstone of its national creed, but this is to miss the point that the state is itself a kind of church for all practical purposes.

23 The other striking thing about the Oath is that it contains several important omissions. While explicitly naming the Constitution as the sacred text of the United States, it respects the taboo on naming the real sacred symbol, i.e. the flag. Nevertheless, while many soldiers would lay down their life to keep an American flag safe, none would risk injury to protect a copy of the Constitution (or even the original document, for that matter). The other important omission in the Soldier's Oath is any reference to killing or dying, which finally are the two basic tasks that the soldier is authorized to do and which sets him/her apart from ordinary citizens. ${ }^{22}$ These allimportant implications are couched in the neutral pledge to obey the President and one's hierarchical superiors in the Army who represent his sovereign authority.

24 The direct and explicit relationship of each soldier to the highest sovereign power in the group articulated in the Soldier's Oath, binding each oath-taker directly to the President, reveals something about why military service occupies such a charged and often coveted place in national experience. Military service confers on soldiers a privileged relationship to totemic power, the power linked to sovereignty and to the most sacred sites, objects and moments in national life. This heightened relationship to 
national belonging is the reason why military service continues to be prized by young men seeking a rite of passage and a link to something greater than their individual lives. It is also the reason why women have fought to be accepted into the military and why African Americans and other ethnic groups have eagerly served in every major war. Military service bears a special relationship to citizenship and offers the promise of unassailable national credentials.

25 And yet, soldiers are often objects of intense popular ambivalence. The negative stereotypes of soldiers as unthinking automatons or lawless brutes are rooted in a common perception that soldiers are qualitatively different from civilians: they are linked to death, either by killing or agreeing to be killed. The unquestioning willingness to die, though appreciable in certain specific circumstances, nevertheless creates suspicion that servicemen are uncritical: naive fools in the best of cases, brainwashed robots in the worst. These negative perceptions are even greater in the case of combat veterans who have killed as well as risked their lives. The fear and contempt aroused by Vietnam veterans in the 1970s (before their rehabilitation by official ceremonies and shifts in media depictions in the mid 1980s) revealed a discomfort that is latent in the civilian attitude towards veterans of any war. The official and public respect accorded to military personnel, all the more ubiquitous and ostentatious since the beginning of the Iraq War, conceals the fact that there is necessarily a tension between civilians, focused on their pleasure and profit, and the class of people designated for exposure to death and injury supposedly to protect them (though, in actual fact, few American wars have been truly defensive, most advancing economic and imperial interests of limited relevance to the majority of the population). Thus, the suspicion and distrust is often mutual (with veterans voicing resentment about having been sent into danger by a population that doesn't seem to appreciate what soldiers have risked and lost). This mutual incomprehension came to a head during the Vietnam War but is always present to some degree.

26 Military service possesses a truly unusual status in relation to the nation-state: it is defined by a direct appropriation of the individual in the service of the group. In fact, the whole point is to de-individualize the individual and to make him as unlike a civilian as possible. Thus, military training is characterized by strict discipline and the foregoing of civilian freedoms. The overt rationale for the strictness of military discipline is to make soldiers effective and to save lives, but an anthropological view would focus on the ritualistic aspect of practices that organize access to legalized murder and self-sacrifice. Surely one of the most shocking images in Michael Moore's anti-war film Fahrenheit 9/11 was that of American soldiers in Iraq drunk and stoned and blasting loud rock music as they careened lawlessly through Iraqi streets shooting from tanks. Moore's objective in showing these images was to undermine the credibility of the entire military operation, since soldiers are supposed to be chaste and sober in order for their access to killing to be acceptable. By showing the irreverent attitude of American servicemen to their mission, Moore wished to show that the war itself was corrupt and wrong. In doing so, he was reviving a cultural narrative that had emerged during the Vietnam War, which characterized the soldiers of that war also as lawless and the war itself as illegal. The image of the Vietnam soldier as insubordinate and generally lawless is often linked to the fact that America failed in Vietnam. In fact, all wars since WWII have been failures, as far as regenerating a collective sense of purpose and national cohesion is concerned: so-called successful ones, such as the 
Panama Invasion and Persian Gulf, as ineffective in this respect as the failures (e.g. Vietnam) and stalemates (e.g. Korea).

27 The issue of why some wars "work" as national rituals of renewal and some do not is the subject of a chapter of Marvin and Ingle's book listing several "conditions" that need to be met. These conditions are rooted in the ritual aspect of the theory and need to be understood in anthropological rather than political terms. First of all, according to Marvin and Ingle, the greater the number of deaths, the greater the effect of national "coming together" and patriotism. The two most "successful" wars in this regard in the history of the United States were the Civil War and World War II. In the first, nearly one in ten able-bodied adult males were killed or injured. In the second, the percentage of deaths relative to the population was smaller, but $82 \%$ of American men between the age of 20 and 25 were drafted or enlisted, and therefore at risk.

28 An important corollary of the first condition is that only member deaths count, not enemy deaths. This would explain why the effects of the First Gulf War, with over 85,000 Iraqi deaths but only 147 American casualties, were so fleeting. Common sense would suggest that such a resounding victory would translate into a longer lasting sense of national unity and pride, but scholars all agree that the war faded quickly from popular memory and concern. Similarly, the War of 1812 (with 2,260 killed), the Mexican American war of 1846-48 (with 1733 deaths) and the Spanish American War of 1898 (with 385) both had little long-term impact on American national self-definition, and even the Korean and Vietnam Wars (with around 50 and 60 thousand casualties, respectively) did not touch nearly as much of the population as WWII with its 400,000 deaths (and over a million combined deaths and wounded).

29 However, Korea and Vietnam failed to meet other ritual conditions listed by Marvin and Ingle, including the requirement that the sacrificial victim must be (or appear to be) willing. The victims, and again, this refers generally to soldiers, must declare themselves willing to die for the cause, and the group must declare itself willing to sacrifice them. If the Soldier's Oath is the formal declaration of the soldier's willingness, an official declaration of war is the standard way in which the nation indicates its willingness to bear the cost of war in soldiers' lives. The Vietnam War was a failure in all respects, as far as this condition is concerned, because first of all, the US government never formally declared war on Vietnam, and secondly U.S. soldiers were increasingly unwilling to die or even fight in the war as it lost popular support in later years.

30 Popular support is, in fact, another condition for a war to have lasting effects on national cohesion. The most reliable producer of what Marvin and Ingle call "unanimous victimage" (i.e. widespread popular consent for member sacrifice) is a credible enemy. ${ }^{23}$ WWII was an ideal war because it offered enemies that were unambiguously worth killing and being killed by. The pretext for war must also be seen as coming from the outside, so as to better conceal the fact that the nation will benefit from its soldiers' deaths. Again, Pearl Harbor offered the US an ideal war situation, and Presidents have always made an effort to create the impression that American military involvement is a reaction to a belligerent attack rather than a preemptive move (e.g. the fictive Gulf of Tonkin missile attack in 1964 cited by Johnson as his casus belli in Vietnam).

31 Fourth, there must be genuine uncertainty of the outcome, and the greater the uncertainty, the greater the ritual magic and enduring effects of the outcome. The 
Revolutionary War, the Civil War and WWII all share this feature. There was no certainty from the start that the American rebels would succeed or that the Southern rebels wouldn't. It is also plausible that Normandy has had such an enduring power over the national imagination because its outcome was so unsure at the time. Similarly, James Bradley's account of the Battle of Iwo Jima in Flags of Our Fathers lays special stress on the way in which the unexpectedly high losses caused "a sickening anxiety" about the outcome of that operation. ${ }^{24}$ It took 23 days to secure the island, far more than anyone predicted, and success was likely but far from guaranteed. Iwo Jima was the only battle of the war where the losses of the victors outnumbered the losses of the defenders.

32 Fifth, the outcome must be definite: victory or loss must be clear and borders reconsecrated in order for time to begin again. The outcome itself is less important than its clarity. Even a loss can have a tremendously unifying effect on a group (one thinks of the Alamo or Weimar Germany). In contrast, an ambiguous outcome, such as that in Korea, cannot create a feeling of national unity. This theory can help explain the memory hole into which the Korean War disappeared in spite of its 36,574 dead and 103,284 American wounded..$^{25}$

33 Finally, only another ritual can repair a failed ritual. It is interesting in this light to see how the First Gulf War was offered by President Bush Sr. as an attempt to repair the failed ritual of the Vietnam War, and how the war in Iraq was understood widely to be Bush Jr.'s attempt to repair the ultimately failed ritual of the First Gulf War. Since popular elections are also social rituals whose ritual agency can be compared to that of member sacrifice, it is important to see how Clinton's election in 1992, on his promise of a "new covenant" with America, and more recently, Obama's election in 2008, were understood by many Americans as rituals that could heal the divisions that have been plaguing America since the failure of the Vietnam War. ${ }^{26}$ Obama's failure to bridge the gap between the left and right in the US (and what political figure could?) has shown how quickly such hopes can evaporate.

34 In the past six decades, the only event that came even close to generating the kind of national feeling Mario Cuomo describes having about WWII was the Sept. 11 attack. Yet the deaths at the Twin Towers ultimately did not have the cohesive effect of the deaths of soldiers at Iwo Jima. For one thing, as already mentioned, most victims of 9/11 were not willing sacrifices in any possible sense of those words. Secondly, even the media sanctification of the firefighters in the immediate aftermath of the attacks, which worked initially to position them like soldiers and therefore like national heroes in their sacrifice, eventually wore off as revelations of the sometimes less than heroic side of firefighters appeared in 2002. For example, William Langewiesche's American Ground: Unbuilding the World Trade Center (2002) took away some of their saintly luster with his description of firefighters treating their own dead with "elaborate flag-draped ceremonials" while adopting a callous "bag "em and tag "em" attitude toward civilian dead. ${ }^{27}$ As a result, tensions arose in the weeks after the attacks between firefighters and the civilian construction workers, who felt that the civilian dead were being forgotten in the media hype about firefighters.

35 Perhaps the biggest reason for the lack of enduring solidarity as an effect of the Sept. 11 attacks is the way the emotions of that day were channeled by the Bush administration into a strategy of revenge that targeted what turned out to be an unrelated country and to have had very ambiguous results. Iraq is no longer ruled by a 
unstable dictator, but the war has brought no tangible benefits to the United States (though many private corporations have profited greatly), and certainly no sense of national regeneration or rededication to a common cause. On the contrary, the war in Iraq has left America heavily in debt and more polarized than ever.

36 Precisely because most wars America has waged have failed so utterly at producing any kind of national solidarity, something that needs to be examined in this discussion of ritual conditions and ritual agency is the question of what level this logic operates on. Clearly, it is not the level of individual actors, since no American official would ever think of himself as sending American soldiers to die in order to strengthen national cohesion. ${ }^{28}$ Even less is this the logic of official state discourse or reasoning. In fact, the ignorance of individuals and states of the advantages of war sacrifice as ritualized social glue is obvious from how often wars are conducted ineptly, from a ritual point of view, robbing them of any efficacy whatsoever. In any case, as Girard insists, and Marvin and Ingle concur, the real motives for the group-member sacrifice must be unknown to the participants of the ritual. ${ }^{29} \mathrm{~A}$ war must seem to be provoked by an external enemy and not sought out by the group. The sacrifice will not work to generate group feeling and solidarity if there is any hint of recognition that the group desired the sacrifice in any way. This split between the explicitly articulated and the tacit ritual meaning of sacrificial violence is the reason why analysis of political speeches, documents, and memos may not explain everything about a nation's behavior. By definition, the collective will and agency operates on a level that is not conscious or epistemologically available to individuals. It is a level that is necessarily supra-individual even though individuals will have their own sense of why they are doing something like enlisting in the military or visiting a national memorial. At the same time, the collective meaning, agency and effects of such actions and institutions will exist on a different plane of social reality than the meaning and effects of individuals' actions and how they perceive them..$^{30}$

37 It is often said that wars are launched as a means of generating unity and distracting a civilian population from domestic discord. This is the cynical commonplace that was made about Clinton's bombing of Serbia and Kosovo as well as Bush Sr.'s decision to attack Iraq in 1990. Like many clichés, it may be partly true, and some wars do indeed create powerful feelings of national solidarity, spawning institutions and commemoration practices that give the country momentum for a while. Yet Marvin and Ingle's theory of blood sacrifice and civil religion suggests that this solidarity comes not from facing or defeating a common enemy, real or invented, but from the deaths of members/soldiers willing to die in the name of the nation. In other words, the only kind of war that could possibly create real national renewal is one that is so cataclysmic that it would cost not thousands, but hundreds of thousands, of lives. If Americans realized that they cannot get national unity with military action on the cheap, perhaps we might rethink our willingness, generation after generation, to believe that war can offer any kind of desirable solution to international conflict. As H.W. Brands reminds us, "during the past two hundred years no country has sent military forces into battle more often than the United States." ${ }^{31}$ If we understood better the mixed motivations that drive American politicians to choose war as a foreign policy option, we might have a better chance at making other choices. If we also understood better the powerful mechanisms at work in collective and national identifications, we might become more adept at creating group solidarity by means of elections and other 
popular democratic processes instead of so often looking for a quick fix of regeneration through violence.

\section{NOTES}

1. I follow Aviel Roshwald in not making a distinction between patriotism and nationalism, which are commonly differentiated into a healthy devotion to an existing state (for the former) and an ideological commitment to establishing a sovereign nation-state (for the latter). Roshwald argues that such a distinction is not useful in understanding the complex relationship between states and the national ideals that they claim to represent. See Aviel Roshwald, The Endurance of Nationalism (Cambridge and New York: Cambridge University Press, 2006), 4. Similarly, I would claim that making a distinction between civic nationalism (such as that of the United States) and religious nationalism (defined by a notion of sacred mission or chosenness) provides no significant critical traction with respect to the United States, which has been defined in terms of the latter as often as the former despite the officially secular status of the Constitution.

2. Tom Nairn, The Break-up of Britain (London: New Left Books, 1977), 329-63.

3. For a divergent view of the War of 1812 see Jaap Verheul's analysis in this issue.

4. Robert Penn Warren, The Legacy of the Civil War (University of Nebraska Press, 1998, 1961), 3.

5. John Neff, Honoring the Civil War Dead (University of Kansas, 2004), 8-10.

6. James McPherson, "Out of War, A New Nation," Prologue Magazine 42.1 (Spring 2010), an online version of this article is available at: http://www.archives.gov/publications/prologue/2010/ spring/newnation.html

7. George Mosse, "National Cemeteries and National Revival: The Cult of the Fallen Soldiers in Germany," Journal of Contemporary History 14/1 (Jan. 1979): 8.

8. Robert Bellah, "Civil Religion in America," Daedalus: Journal of the American Academy of Arts and Sciences 96 (1967): 1-21. Bellah's use of the term is signifantly different from mine since he is concerned mainly with the Christian structure of American legitimating myths, and focuses his analysis on the content of Presidential speeches. Although I examine Lincoln's speech carefully, my larger interest is not textual so much as anthropological, focusing on the forms and rites of national observance rather than its doctrine or expressed content.

9. In Lincoln at Gettysburg, Garry Wills compares the speech to Athenian Epitaphioi (funeral orations), where the "Attic citizens" are "earth-born" (autochthones) in the sense that they are produced by both the traditions of the fathers (progonoi) and the "motherhood of the earth itself," but this does not explain how a nation is reborn from the deaths of its citizens. See Garry Wills, Lincoln at Gettysburg: The Words That Remade America (New York: Simon \& Schuster, 1992), 77. 10. Concrete evidence of the way World War One is overshadowed by the Civil War and WWII in national historical memory is the small space devoted to it at the Smithsonian Museum in Washington, D.C., a key institution of national commemoration. According to Scott Boehm, the World War One part of the permanent Price of Freedom exhibition, documenting American wars from independence to Iraqi Freedom, is "paltry" compared to other displays. See "Privatizing Public Memory: The Price of Patriotic Philanthropy and the Post-9/11 Politics of Display," American Quarterly 58: 4 (Dec. 2006): 1163.

11. New York Times, March 19, 1995: 41. 
12. By "choreographed, " I refer to the way the flag-planting as a whole was a morale-boosting symbolic event, and do not mean to imply that the planting was staged for the photo, as has sometimes been claimed. See Karal Ann Marling and John Wetenhall, Iwo Jima: Monuments, Memories, and the American Hero (Cambridge: Harvard University Press, 1991), 67-79.

13. The New York Times, Sept. 27, 2007. http://www.nytimes.com/2007/09/27/nyregion/ 27survivor.html. Accessed June 14, 2010.

14. Benedict Anderson, Imagined Communities (London: Verso, 1983), 129.

15. There are other groups who occasionally attempt to re-appropriate this power for themselves, e.g. religious sects, gangs, militias, but they can only appropriate this power from the nation and so they become illegal organizations the moment they claim the right to manage member life and death in the same way the nation-state is permitted.

16. Emile Durkheim, The Elementary Forms of the Religious Life, translated by Joseph Ward Swain (New York: The Free Press, 1915, 1965), 236.

17. Marvin and Ingle point out that there are two kinds of flags: totemic flags, such as those used on official occasions and linked to the rituals and institutions of state power, and popular flags, which come in all shapes and sizes and are used by ordinary people on popular occasions. Only the first are subject to special protocols of production, handling and disposal, and only these possess the quasi-mystical power that is attributed to the totem. See Marvin and Ingle, Blood Sacrifice, 217.

18. The 1940 Supreme Court decision Minersville School District v. Gobitis ruled that the flag was not a religious object and that saluting it was therefore not an issue covered by the First Amendment. The result was that the Johovah's Witnesses were refused exemption from saluting the flag and reciting the Pledge of Allegiance. Three years later the Supreme Court revisited the issue and ruled the other way (possibly in light of increased revulsion at the Nazi regime and its compulsory forms of national celebration). The 1943 Supreme Court decision Burnette v. The West Virginia Board of Education permitted Jehovah's Witnesses to refuse to salute the flag and recite the Pledge of Allegiance, thus, according to Marvin and Ingle, indirectly acknowledging the religious status of the flag and the oath. See Blood Sacrifice, p. 28. For a discussion of the possible motives behind the Supreme Court's reversal, see Arnaldo Testi, Capture the Flag: The Stars and Stripes in American History (New York and London: New York University Press, 2010), 48-50.

19. Though admittedly the degree of respect accorded the flag varies widely, and according to British psychologist Michael Billig, only the United States is currently the "home of what Renan called 'the cult of the flag." See Michael Billig, Banal Nationalism (London: Sage, 1995), 39.

20. Anthony Marx, Faith in Nation: Exclusionary Origins of Nationalism (New York: Oxford University Press, 2003), 25-29.

21. Nevertheless, sacrifice is not the only ritual that unifies and regenerates nations, according to Marvin and Ingle. They devote a large part of their book to the electoral process, and the ritualistic aspects of voting, sovereignty, and inaugurations, which they analyze in anthropological terms.

22. The founder of a blog called the "Oathkeeper's blogspot" writes at the beginning of his blog: "This is the Soldiers Oath I voluntarily took back in May of 1981. The day I took this pledge was a defining moment of my life. I still get emotional just reading it. You see, I knew full well (or thought I did) the implications of the Oath and the responsibilities that I was assuming. I was taking my place in that long line of idealistic young men and women, Patriots, who would, if necessary, give their lives in the defense of this great Nation." The Oathkeeper's Blogspot is a webpage for members of the military or other uniformed services who are uncomfortable with the use of the military to police American citizens or violate the Constitution. Yet, in spite of their wide-ranging resistance to the notion of "blindly following orders" and their willingness to refuse orders that violate the Bill of Rights, there is no trace of any reservations about the tacit willingness of any soldier or uniformed person to sacrifice their life if required in the line of 
duty. This is apparently an aspect of national service that is beyond all rational examination. Source: http://oath-keepers.blogspot.com/2009/03/soldiers-oath.html Accessed on April 7, 2010. Last accessed on April 7, 2010.

23. Blood Sacrifice, 90-91.

24. James Bradley, with Ron Powers, Flags of Our Fathers (New York: Bantam, 2000), 334.

25. Source: Anne Leland and Mari-Jana Oboroceanu, "American War and Military Casualties: Lists and Statistics," Congressional Research Service, February 26, 2010, 3.

26. Marvin and Ingle have an entire chapter on American quadrennial presidential elections as "contrived group crisis" which select a totem leader for "future sacrifice." See Blood Sacrifice, 248. This process can be as regenerative as a successful blood sacrifice, which it parallels in structure, they argue, but usually lacks the "impact" of the latter (250).

27. William Langewiesche, American Ground: Unbuilding the World Trade Center (New York: North Point Press, 2002), 70.

28. However, the cynical realpolitik of American neocons comes very close. For example, according to Ashley Dawson and Malini Scheuller, drawing on Anne Norton's work, Paul Wolfowitz and his circle believe that "the United States can be united only when confronted by an external threat and that if such a threat does not exist, it must be manufactured." See Dawson and Scheuller, Exceptional State: Contemporary U.S. Culture and the New Imperialism. Durham and London: Duke University Press, 2007), 17, and Anne Norton, Leo Strauss and the Politics of American Empire (New Haven: Yale University Press, 2005). The reasoning here is very close to that of Réné Girard and the logic of the sacrifice as a means to channel social aggression and tension to a scapegoat. See Réné Girard, Violence and the Sacred, trans. Patrick Gregory (Baltimore: The Johns Hopkins University Press, 1977, 1972).

29. See Girard, Violence and the Sacred, 7.

30. Durkheim theorized this supra-individual level of agency and motivation with what he called homo duplex. With this notion Durkheim sought to account for how, "in so far as he belongs to society, the individual transcends himself, both when he thinks and when he acts." This "transcendent" level of thought and action is the level on which the social logic of group feeling and blood sacrifice should be understood. See Durkheim, Elementary Forms, 29. In Victor Turner's tri-part classification of the meanings of a symbol or ritual, the "positional" level, which remains unconscious or hidden from participants and refers to the symbol's relationship to other symbols in a total ritual system, could also be applied to this theory. See Victor Turner, The Forest of Symbols: Aspects of Ndembu Ritual (Ithaca: Cornell University Press, 1967), 50-52.

31. H.W. Brands, "Preface: War and Forgetfulness," Revue française d'études américaines 107 (mars 2006): 9.

\section{ABSTRACTS}

Wars are often associated with a rhetoric of renewal or new beginnings. This essay explores this claim through the lens of civil religion and a recent book by Carolyn Marvin and David Ingle, Blood Sacrifice and the Nation, which combines Emile Durkheim with Réné Girard in proposing that modern national cohesion depends on blood sacrifice. I unpack some of the paradoxes raised by this theory of national renewal in the context of $9 / 11$, with a special focus on the sacred status of the flag and the special attention given to uniformed serviceman in the American body politic 


\section{INDEX}

Keywords: 9/11, Abraham Lincoln, Benedict Anderson, Carolyn Marvin, civil religion, Civil War, David Ingle, death, Emile Durkheim, flag, freedom, Gary Wills, Gettysburg Address, Iwo Jima, military, nationalism, patriotism, Réné Girard, renewal, ritual, Robert Bellah, Robert Penn Warren, self-sacrifice, Soldier's Oath, Thomas Franklin, United States, war

\section{AUTHOR}

\section{AGNIESZKA SOLTYSIK MONNET}

Université de Lausanne 